\title{
Analisis Perkembangan Titer Antibodi Hasil Vaksinasi Infectious Bronchitis pada Ayam Petelur Strain Hisex Brown
}

\author{
Yenni Tyas Wulandari K. $\mathrm{E}^{凶}$, R. Susanti, dan Siti Harnina Bintari
}

Jurusan Biologi, Fakultas Matematika dan Ilmu Pengetahuan Alam Universitas Negeri Semarang, Indonesia

\begin{tabular}{l} 
Info Artikel \\
\hline Diterima: 1 Maret 2019 \\
Disetujui: 30 Maret 2019 \\
Dipublikasikan: 25 April \\
2019 \\
Keywords: \\
Infectious bronchitis, vaksin \\
IB, Titer antibodi, Strain \\
Hisex Brown \\
\hline
\end{tabular}

\begin{abstract}
Infectious bronchitis (IB) is a disease that attacks the chicken's respiratory system caused by an infectious bronchitis virus. IB transmission can occur directly and indirectly. IB disease transmission can be done by vaccination. Vaccination can fail so that to determine the success of the vaccination program an antibody titer monitor is performed using serological tests. ELISA is one of the serological tests that can be used to measure antigens/antibodies. The main principle of the ELISA technique is the use of enzyme indicators for immunological reactions. This study aims to analyze the differences in chicken antibody titers at certain periods after vaccination. The sample in this study used 18 female layer hens of Hisex Brown Strain aged 20 weeks that were vaccinated by IB. This study was an experimental study with treatment of antibody titer measurements at 7, 14, and 21 days after vaccination. Data analysis is descriptive quantitative using the Normality test and t test. The mean results of antibody titers at each consecutive time period at 7, 14, and 21 days after vaccination were 1695, 4207, and 5978. The results of the t test showed that at each sampling period $7 \mathrm{dpi}, 14 \mathrm{dpi}$ and $21 \mathrm{dpi}$ had differences significant. The number of titers of IgG antibodies to the IBV virus increases from a distance after vaccination. Conclusions were obtained that antibodies increased in each period of time taken after vaccination.
\end{abstract}

\begin{abstract}
Abstrak
Penyakit Infectious bronchitis (IB) adalah penyakit yang menyerang sistem pernafasan ayam yang disebabkan oleh Infectious bronchitis virus. Penularan IB dapat terjadi secara langsung dan tidak langsung. Penularan penyakit IB dapat dilakukan dengan cara vaksinasi. Vaksinasi dapat mengalami kegagalan sehingga untuk mengetahui keberhasilan program vaksinasi dilakukan monitor titer antibodi menggunakan uji serologis. ELISA adalah salah satu uji serologis yang dapat digunakan untuk mengukur antigen/antibodi. Prinsip utama teknik ELISA adalah penggunaan indikator enzim untuk reaksi imunologi. Penelitian ini bertujuan menganalisis adanya perbedaan titer antibodi ayam pada periode tertentu setelah vaksinasi. Sampel pada penelitian ini menggunakan 18 ekor ayam petelur betina Strain Hisex Brown umur 20 minggu yang divaksin IB. Penelitian ini merupakan penelitian eksperimental dengan perlakuan pengukuran titer antibodi pada 7, 14, dan 21 hari setelah vaksinasi. Analisis data secara deskriptif kuantitatif menggunakan uji Normalitas dan uji t. Rerata hasil titer antibodi pada setiap periode waktu berturut-turut pada 7, 14, dan 21 hari setelah vaksinasi yaitu 1695, 4207, dan 5978. Hasil uji t menunjukkan pada setiap periode pengambilan sampel yaitu $7 \mathrm{dpi}, 14 \mathrm{dpi}$, dan 21 dpi mempunyai perbedaan yang signifikan. Jumlah titer antibodi IgG terhadap virus IBV semakin meningkat dari jarak setelah vaksinasi. Kesimpulan yang diperoleh bahwa antibodi mengalami peningkatan pada setiap periode waktu pengambilan setelah vaksinasi.
\end{abstract}

(C) 2019 Universitas Negeri Semarang p-ISSN 2252-6277

${ }^{凶}$ Alamat korespondensi:

e-ISSN 2528-5009

Gedung D6 Lt.1 J1 Raya Sekaran Gunugpati, Semarang

E-mail: tyasyenni@gmail.com 


\section{PENDAHULUAN}

Kabupaten Karanganyar merupakan salah satu kabupaten dengan peternakan yang cukup banyak tersebar di berbagai wilayah. Beberapa lokasi peternakan berada jauh dari pemukiman dan di lingkungan rumah. Data terakhir dari Badan Pusat Statistik Dinas Peternakan dan Perikanan Kabupaten Karanganyar pada tahun 2015, jenis ternak terbanyak di Kabupaten Karanganyar yaitu ayam ras sebanyak 1.830.060 ekor dan 918.961 ekor ayam buras (BPS, 2017). Namun, usaha peternakan ayam sering terkendala oleh berbagai penyakit menular. Penyakit Infectious Bronchitis juga sering muncul dan menjadi permasalahan pada peternakan ayam (Kencana et al., 2015).

Penyakit Infectious Bronchitis adalah penyakit yang menyerang sistem pernafasan ayam yang disebabkan oleh virus infectious bronchitis. Infectious Bronchitis merupakan anggota dari famili Coronavidae (Order Nidovirales) dan genus Coronavirus yang menyebabkan infeksi pernafasan, usus, dan bermacam-macam gangguan neurologis lainnya (Cao et al., 2012). Penyakit IB di Indonesia masih menjadi masalah serius pada ayam sehubungan dengan banyak varian yang timbul akibat mutasi dari virus IB (Dharmayanti et al., 2017). Gejala penyakit IB pada ayam hampir sama dengan ND, sehingga masyarakat lebih sering melakukan monitoring terhadap ND daripada IB.

Menurut Kencana et al., (2015), penularan IB dapat terjadi secara langsung dan tidak langsung. Penularan penyakit secara langsung berasal dari ayam satu ke ayam yang lain dalam satu kandang, sedangkan penularan penyakit secara tidak langsung melalui petugas dan peralatan kandang yang tercemar virus. Ada beberapa cara untuk mencegah penularan penyakit salah satunya yaitu vaksinasi.

Vaksinasi adalah salah satu tindakan pencegahan dan pengendalian penyakit (Sasipreeyajan et al., 2012). Vaksinasi yang tepat dan teratur dapat menurunkan kerentanan terhadap infeksi virus. Namun, vaksinasi yang dilakukan dapat pula mengalami kegagalan. Menurut Putri et al., (2012), banyak faktor penyebab respon vaksinasi yang dihasilkan tidak sesuai dengan yang diharapkan yaitu jenis vaksin, dosis vaksin, aplikasi vaksin, serta program vaksinasi yang dilakukan.

Frekuensi kejadian IB di Indonesia lebih sering terjadi pada ayam petelur dibanding ayam pedaging. Kasus IB masih sering muncul meskipun vaksinasi sudah diterapkan. Program vaksinasi terhadap IB adalah salah satu faktor pendukung kejadian penyakit di Indonesia (Direktorat Kesehatan Hewan, 2014). Program vaksinasi yang dilakukan tidak sesuai dengan kondisi setiap ayam sehingga menyebabkan respon imun ayam berbeda. Program vaksinasi memerlukan penjagaan dan kontrol agar penyebaran virus dapat dicegah (Bande et al., 2016). Selain itu, menurut Sattler et al., (2014), deteksi serologi terhadap antibodi adalah salah satu metode yang efektif untuk mengetahui keberhasilan vaksinasi.

Uji serologis yang biasa digunakan adalah Enzyme-Linked Immunosorbent Assay (ELISA). Setelah vaksinasi akan muncul respon antibodi sehingga terbentuk antibodi yang dapat diukur menggunakan ELISA. Berdasarkan latar belakang tersebut, maka penelitian untuk menganalisis perkembangan titer antibodi pada setiap periode waktu sangat diperlukan sebagai upaya memonitor terhadap kondisi titer antibodi dari program vaksinasi yang dilakukan. 


\section{METODE}

Penelitian ini merupakan penelitian ekperimental, ayam petelur Strain Hisex Brown divaksin menggunakan vaksin IBV kemudian dilakukan pengamatan titer antibodi hasil vaksinasi pada 7, 14, dan 21 hari setelah vaksinasi. Variabel dalam penelitian ini yaitu variabel bebas berupa interval pengambilan sampel darah dari ayam yang telah divaksin IBV dan variabel terikat berupa titer antibodi ayam terhadap vaksin IBV. Pengambilan sampel darah ayam dilakukan di peternakan Ngelom, Sroyo, Jaten, Karanganyar. Penelitian dilakukan di Laboratorium Kesehatan Hewan Type B Surakarta J1. Balekambang Utara No.3, Manahan, Banjarsari, Surakarta. Penelitian dilakukan pada bulan April 2018 sampai Mei 2018. Prosedur penelitian berturut-turut yang dilakukan yaitu: pengambilan sampel darah, isolasi serum sampel, dan pengujian ELISA.

\section{Pengambilan sampel darah}

Sampel darah ayam diambil melalui vena pectoralis sebanyak minimal $1 \mathrm{ml}$ dengan menggunakan spuit $3 \mathrm{ml}$. Sampel darah dibiarkan beberapa saat dalam posisi miring hingga darah menggumpal.

\section{Isolasi serum sampel}

Sampel darah yang telah diambil diletakkan pada suhu kamar selama $\pm 1-2$ jam. Setelah itu diletakkan pada suhu $4^{\circ} \mathrm{C}$ selama 18-24 jam. Sampel yang belum keluar serumnya disentrifugasi dengan kecepatan 2500 rpm selama 10 menit. Kemudian serum dipisahkan dari bagian darah yang menggumpal. Serum ditampung pada tube steril dan sampel diinaktivasi dalam penangas air suhu $56^{\circ} \mathrm{C}$ selama 30 menit, kemudian serum disimpan pada suhu $-20^{\circ} \mathrm{C}$ (Syukron et al., 2013).

\section{Pengujian ELISA}

Tahap pertama adalah persiapan serum sampel yaitu serum sampel dimasukkan ke dalam pelarut phosphate buffer solution (PBS) dengan perbandingan 1:500 ke dalam tube 1,5 $\mathrm{ml}$ dan inkubasi selama 30 menit pada suhu kamar. Sampel ditambah larutan diluent sebanyak $500 \mu 1$ kemudian dipipetting agar homogen.

Tahap kedua adalah prosedur ELISA dengan tipe indirect dari kit IDEXX IBV. Kontrol negatif, kontrol positif, dan serum sampel sebanyak $100 \mu \mathrm{l}$ dimasukkan ke dalam lubang mikroplate, masingmasing kontrol dibuat duplo. Kontrol dan serum diinkubasi selama 30 menit pada suhu kamar. Mikroplate dicuci dengan akuades. Conjugate sebanyak $100 \mu \mathrm{l}$ dimasukkan ke dalam lubang kontrol negatif, kontrol positif, dan sampel pada mikroplate dan diinkubasi selama 30 menit pada suhu kamar. Mikroplate dicuci dengan akuades. Substrat tetramethylbenzidine (TMB) sebanyak $100 \mu 1$ dimasukkan ke dalam lubang kontrol negatif, kontrol positif, dan sampel pada mikroplate dan diinkubasi selama 15 menit pada suhu kamar. Stop solution sebanyak $100 \mu \mathrm{l}$ dimasukkan ke dalam lubang kontrol negatif, kontrol positif, dan sampel pada mikroplate. Sampel diukur dengan ELISA reader dengan filter $650 \mathrm{~nm}$ dan hasil dikalkulasi dengan $\mathrm{S} / \mathrm{P}$ ratio.

Perhitungan sample value related to positive value $(\mathrm{S} / \mathrm{P})$ dihitung dengan formula sebagai berikut.

$$
S / P=\frac{\text { Sample OD } 650-\text { Mean OD kontrol negatif }}{\text { Mean OD kontrol positif - Mean OD kontrol negatif }}
$$


Perhitungan titer

$\log _{10}$ Titer $=1.09\left(\log _{10} \mathrm{~S} / \mathrm{P}\right)+3.36($ ELISA kit IDEXX IBV)

Hasil diintepretasi dengan $\mathrm{S} / \mathrm{P}$ ratio kurang dari 0,25 adalah negatif dan $\mathrm{S} / \mathrm{P}$ ratio sama atau lebih dari 0,25 adalah positif.

Tabel 1. Interpretasi hasil uji ELISA

\begin{tabular}{ccc}
\hline $\mathbf{S} / \mathbf{P}$ & Titer & Interpretasi \\
\hline $\mathrm{S} / \mathrm{P}<0,20$ & $<396$ & Negatif \\
$\mathrm{S} / \mathrm{P}>0,20$ & $>396$ & Positif \\
\hline
\end{tabular}

Analisis data berupa deskriptif kuantitatif. Analisis kuantitatif menggunakan uji Normalitas dan uji t. Uji Normalitas data menggunakan metode Kolmogorov-Smirnov menggunakan selisih dari data yaitu pada 7 dpi dan 14 dpi serta selisih data 14 dpi dan 21 dpi. Hal tersebut karena uji t-paired yang digunakan mengasumsikan bahwa perbedaan antara pasangan data berdistribusi normal. Data menunjukkan berdistribusi normal apabila diperoleh nilai lebih dari taraf signifikan 0,05 . Ketika kedua selisih data menunjukkan data berdistribusi normal maka dapat dilakukan uji t-paired. Analisis uji $\mathrm{t}$ dilakukan pada 7 dpi dan 14 dpi serta 14 dpi dan 21 dpi.

\section{HASIL DAN PEMBAHASAN}

Hasil vaksinasi Infectious Bronchitis pada ayam yang diuji menggunakan ELISA menunjukkan bahwa antibodi muncul pada 7 hari setelah vaksinasi. Pada 14 hari dan 21 hari setelah vaksinasi ratarata titer antibodi mengalami peningkatan. Nilai titer antibodi dari 18 sampel pada setiap periode waktu pengambilan tercantum pada Tabel 2 .

Tabel 2. Nilai Titer Antibodi

\begin{tabular}{cccc}
\hline \multirow{2}{*}{ Sampel } & \multicolumn{3}{c}{ Pengukuran hari ke- } \\
\cline { 2 - 4 } & $\mathbf{7 ~ d p i}$ & $\mathbf{1 4} \mathbf{~ d p i}$ & 21 dpi \\
\hline 1 & 4218 & 6181 & 4120 \\
2 & 3365 & 5567 & 5746 \\
3 & 2315 & 4003 & 4120 \\
4 & 1604 & 2450 & 7341 \\
5 & 1620 & 4876 & 8930 \\
6 & 2645 & 2787 & 12104 \\
7 & 874 & 5120 & 5233 \\
8 & 2728 & 2859 & 3162 \\
9 & 996 & 8562 & 8966 \\
10 & 1973 & 7238 & 7201 \\
11 & 1165 & 4485 & 3887 \\
12 & 1893 & 4233 & 7798 \\
13 & 1668 & 4133 & 7376 \\
14 & 489 & 3838 & 6574 \\
15 & 2070 & 2520 & 2100 \\
16 & 223 & 4970 & 7727 \\
17 & 347 & 1276 & 4020
\end{tabular}




\begin{tabular}{cccc}
\hline \multirow{2}{*}{ Sampel } & \multicolumn{3}{c}{ Pengukuran hari ke- } \\
\cline { 2 - 4 } & $\mathbf{7 ~ d p i}$ & $\mathbf{1 4} \mathbf{d p i}$ & $\mathbf{2 1} \mathbf{d p i}$ \\
\hline 18 & 319 & 623 & 1203 \\
\hline Rata-rata & $\mathbf{1 6 9 5}$ & $\mathbf{4 2 0 7}$ & $\mathbf{5 9 7 8}$ \\
\hline
\end{tabular}

Keterangan:

dpi $=$ day post infection

Selisih nilai titer antibodi dari setiap sampel pada selang waktu 7 dan 14 hari setelah vaksinasi mempunyai nilai yang berbeda dengan selisih nilai titer antibodi pada 14 dan 21 hari setelah vaksinasi. Tinggi rendahnya titer antibodi dapat diketahui setelah penambahan stop solution yang menghentikan reaksi substrat TMB setelah munculnya warna biru pada mikroplate seperti pada Gambar 1. Pada lubang microplate ELISA terdapat 8 baris dan 12 kolom. Urutan peletakan kontrol dan sampel sesuai dengan urutan baris kemudian kolom. Penggunaan microplate sesuaikan dengan jumlah sampel yang akan diuji.

F G H

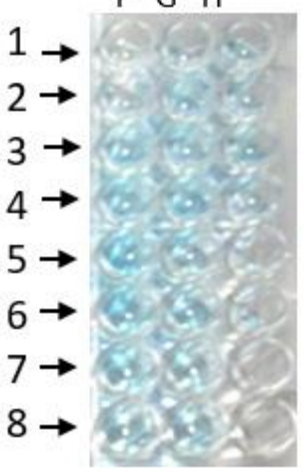

A

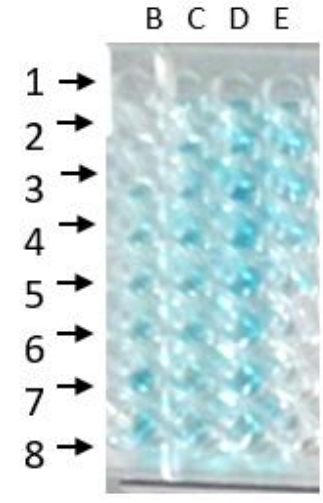

B

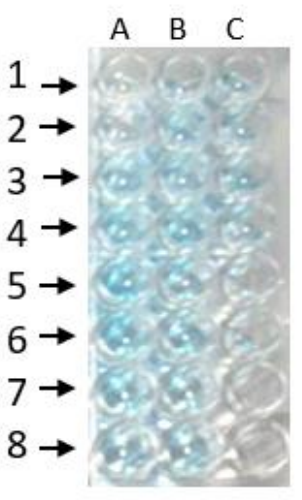

C

Gambar 1. Mikroplate hasil pengujian ELISA. (A) 7 hari setelah vaksinasi, (B) 14 hari setelah vaksinasi, dan (C) 21 hari setelah vaksinasi

Perbedaan selisih titer antibodi dihitung dengan uji t-paired menggunakan SPSS. Sebelum diuji t, selisih data dihitung normalitasnya menggunakan One sample Kolmogorov-Smirnov test. Hasilnya, semua selisih data pada 7 dpi dan 14 dpi dan 14 dpi dan 21 dpi menunjukkan bahwa data berdistribusi normal. Ada 2 analisis uji t yang dihitung yaitu uji t pada 7 dan 14 dpi dan uji t pada 14 dan 21 dpi. Taraf signifikansi menggunakan 0,05. Pada uji t 7 dpi dan 14 dpi diperoleh nilai Sig. (2-tailed) 0,000 maka $\mathrm{H}_{0}$ ditolak. Artinya ada perbedaan yang signifikan mengenai selisih titer antibodi pada 7 dpi dan 14 dpi. Sedangkan uji t 14 dan 21 dpi diperoleh nilai Sig. (2-tailed) 0,012 sehingga $\mathrm{H}_{0}$ ditolak. Artinya ada perbedaan yang signifikan mengenai selisih titer antibodi pada 14 dpi dan 21 dpi.

Pengukuran titer antibodi merupakan suatu cara memonitor titer antibodi. Pada vaksin tersebut mengandung virus IB yang mempunyai protein $\mathrm{S} 1$ dan $\mathrm{N}$ yang berperan utama dalam respon imun humoral dan seluler. Glikoprotein S1 mengandung epitop untuk netralisasi, perlekatan sel dan spesifitas serotip. Epitop tersebut yang akan berikatan dengan antibodi (Yuan et al., 2018).

Apabila ada antigen yang masuk ke dalam tubuh akan terjadi pembentukan antibodi oleh sel $\mathrm{B}$. Di dalam tubuh akan terjadi proses penelanan antigen yang masuk ke dalam tubuh oleh makrofag. Enzim- 
enzim di dalam makrofag memotong protein antigen menjadi bagian yang lebih kecil, disebut fragmen antigen. Fragmen antigen di dalam sel berikatan dengan komponen molekul MHC kelas II yang merupakan molekul yang berperan dalam menginisiasiasi respon imun. Ikatan fragmen antigen dan MHC lalu ditranspot ke permukaan sel. Kombinasi molekul MHC dan fragmen antigen dikenali oleh sel $\mathrm{T}$ helper. Sel T helper mengaktifkan sel B untuk memproduksi antibodi. Aktivasi sel B dibantu oleh sitokin yang disekresikan oleh sel helper sehingga sel berproliferasi dan berdifferensiasi menjadi klona sel plasma penyekresi antibodi dan klona sel B ingatan (Campbell et al., 2008).

Pembentukan antibodi akan lebih cepat dan lebih banyak ketika antigen yang sama ke dalam tubuh. Sel T memori akan segera mengenali antigen yang pernah dikenali sebelumnya dan membantu sel B untuk berproliferasi dan menghasilkan sel plasma. Antibodi tersebut akan dilepas ke dalam sirkulasi darah dan dapat diperoleh dalam serum darah untuk menghadapi antigen asing, sehingga mengatur respon imun humoral (Hasnita et al., 2017).

ELISA merupakan salah satu uji serologi yang dapat digunakan untuk mendeteksi antibodi. Prinsip utama teknik ELISA adalah penggunaan indikator enzim untuk reaksi imunologi. ELISA digunakan untuk mendeteksi IgG yang diproduksi setelah infeksi (Akonor et al., 2018). IgG terbentuk setelah IgM yang merupakan respon paling awal dan jumlah terbanyak ketika vaksinasi pertama. IgG adalah antibodi utama yang dihasilkan setelah vaksinasi dan imunoglobulin yang dominan dalam serum darah. Selain itu, IgG membangun sistem pertahanan terhadap bakteri dan virus.

Komponen ELISA terdiri dari pelat polistirene, sampel diluent, kontrol, konjugat, substrat, dan stop solution. Pengenceran serum darah pada awal pengujian bertujuan untuk mengurangi reaksi non spesifik antigen antibodi spesifik dan dapat meningkatkan spesifitas. Pelat yang digunakan berupa fase padat dilapisi oleh antigen dan menjadi tempat pengikatan antibodi dalam sampel. Pelapisan antigen terjadi secara adsorpsi pasif ke permukaan mikroplat karena adanya interaksi hidrofobik antara protein dan permukaan pelat sehingga molekul IgG dapat berikatan dengan antigen pada plate melalui Fc dari IgG (KPL, 2013). Reaksi antara antigen dan antibodi dipengaruhi oleh beberapa faktor di antaranya temperatur, waktu inkubasi dan $\mathrm{pH}$ (kondisi buffer). Langkah pencucian diperlukan untuk menghilangkan antibodi yang tidak terikat dari pelat (Jiang et al., 2014)

Sampel diluent berupa pengencer yang spesifik terhadap sampel kontrol positif berupa reagen yang mengandung IgG spesifik IBV sedangkan kontrol negatif adalah reagen yang tidak mengandung IgG spesifik IBV. Kontrol digunakan untuk memvalidasi pengujian dan menghitung hasil sampel.

Komponen yang lain yaitu konjugat yaitu antibodi yang telah diberi label dengan enzim yang bereaksi khusus terhadap serum sampel. Pada penelitian ini, ELISA yang digunakan adalah ELISA indirect yang akan mengkonjugasikan Ab sekunder dengan enzim sehingga menjadi konjugat Ab-enzim. Konjugat yang biasa digunakan antigenik terhadap IgG ayam sehingga konjugat hanya akan berikatan dengan IgG ayam. Pada ELISA indirect, enzim peroksidase konjugat yang digunakan adalah Horse-radish Peroxidase (HRP) berlabel IgG rabbit anti-chicken sebagai antibodi sekunder (Indriani \& Dharmayanti, 2013). Antibodi tersebut dapat berikatan dengan berbagai epitop sehingga tingkat spesifitas dapat lebih baik (Lougovskaia et al., 2010). HRP adalah enzim yang digunakan untuk memperkuat sinyal dalam tes 
fotometri dengan mengkatalisasi konversi substrat kromogenik. Konjugat enzim HRP mengikat antibodi yang telah terikat. Jenis substrat yang sering digunakan enzim HRP dalam ELISA adalah 3,3', 5,5'tetramethylbenzidine (TMB). Substrat tersebut bereaksi dengan bagian enzim yang terikat dan menghasilkan warna biru pada absorbansi $650 \mathrm{~nm}$ setelah reaksi dengan HRP. Stop solution berupa blocking reagent yang akan menghentikan reaksi enzim-substrat (Suryadi et al., 2009).

Warna yang dihasilkan dibaca dengan ELISA reader sehingga diperoleh kepadatan optik (OD). Nilai OD yang dihasilkan berbanding lurus dengan jumlah enzim yang terikat. Interpretasi hasil titer antibodi dinyatakan sebagai rasio signal-to-noise (S/N) (Lougovskaia et al., 2010). Hasil ELISA berupa nilai absorbansi sehingga dikonversikan menjadi antilog dari log 10 titer.

Pada sampel 16, 17, dan 18 pada 7 hari setelah vaksinasi menunjukkan titer antibodi kurang dari 396 dengan interpretasi negatif. Titer antibodi IBV mempunyai beberapa tingkatan (Akonor et al., 2018) yaitu rendah pada rentang 397-1000. Pada 7 dpi terdapat 16\%, pada 14 dpi terdapat 5\% sedangkan pada 21 dpi tidak ada titer antibodi yang rendah. Tingkatan kedua yaitu medium yang berada pada rentang 1001-5000. Pada 7 dan 14 dpi terdapat 66\% sampel bertiter medium sedangkan pada 21 dpi terdapat 38\% sampel dengan titer medium. Titer tinggi berada pada rentang $>5000$, titer ini terdapat pada $14 \mathrm{dpi}(27 \%)$ dan sebagian besar (61\%) pada 21 dpi. Berdasarkan nilai OD hasil ELISA yang dihitung dan diubah menjadi titer menunjukkan peningkatan titer pada 3 minggu pertama setelah vaksinasi (Ghadakchi et al., 2005).

Hasil penelitian menunjukkan bahwa antibodi muncul pada 7 hari setelah vaksinasi dan mengalami peningkatan pada 14 hari setelah vaksinasi. Hal tersebut sesuai dengan penelitian Cao et al. (2012). Pada Pada 21 hari setelah vaksinasi terjadi peningkatan titer antibodi, tetapi pada beberapa sampel menunjukkan penurunan titer antibodi. Antibodi yang terbentuk di dalam tubuh mempunyai waktu paruh. Pada minggu tertentu jumlah antibodi akan terjadi penurunan karena adanya waktu paruh antibodi tersebut. Waktu paruh antibodi adalah waktu yang diperlukan antibodi berkurang jumlahnya setengah dari antibodi awal (Kencana et al., 2016).

Perbedaan tingkat respons antibodi pascavaksinasi pada ayam dapat dipengaruhi oleh beberapa aspek di antaranya adalah adanya perbedaan sifat antigenik dari virus vaksin yang digunakan, kualitas antigen, serta kandungan komposisi adjuvant (Indriani \& Ni Luh, 2013). Berdasarkan kedua uji t menunjukkan bahwa pada setiap periode waktu pengambilan sampel yaitu 7 dpi, 14 dpi, dan 21 dpi mempunyai perbedaan yang signifikan, hal tersebut sesuai dengan Kencana et al. (2016), Kencana et al. (2017), dan Siswanto et al. (2016) yang menunjukkan bahwa rata-rata titer antibodi yang meningkat signifikan pada setiap minggunya.

Pengukuran titer antibodi setelah vaksinasi dapat digunakan untuk mengetahui keberhasilan vaksinasi. Vaksinasi akan menghasilkan antibodi pada ayam yang divaksin. Antibodi tersebut menunjukkan tingkat kekebalan tubuh ayam terhadap penyakit tertentu (Kencana et al., 2017). Monitoring titer antibodi dapat digunakan untuk mengetahui potensi vaksin dalam memicu kekebalan protektif di lapangan sehingga penyebaran virus dapat diketahui (Kencana et al., 2016). 


\section{SIMPULAN}

Nilai rata-rata titer antibodi hasil vaksinasi kedua Infectious bronchitis pada 7, 14, dan 21 hari setelah vaksinasi menggunakan ELISA yaitu 1695, 4207, dan 5978. Dapat disimpulkan bahwa jumlah titer antibodi IgG terhadap virus IBV semakin meningkat dari jarak setelah vaksinasi.

\section{DAFTAR PUSTAKA}

Akonor M., Kwasi O., Paa T., \& Holly S. (2018). Widespread exposure to infectious bronchitis virus and Mycoplasma gallisepticum in chickens in the Ga-East district of Accra, Ghana. Coagent Foof \& Agriculture, (4) 1439260,1-11.

Badan Pusat Statistik. (2017). Dinas Peternakan dan Perikanan Kabupaten Karanganyar. On line at $<$ http://karanganyarkab.bps.go.id/LinkTableStatis > [diakses tanggal 26 Oktober 2017]

Bande F., Siti S.A., Abdul R.O., Mohd H.B, Muhammad.S.A., \& Yusuf A. (2016). Pathogenesis and Diagnostic Approaches of Avian Infectious Bronchitis. Advances in Virology, 11, 1-11.

Cao Z., Zongxi H., Yuhao S., Xiaoli L., Junfeng S., Demin Y., Xiangang K., \& Shengwang L. (2012). Proteomics Analysis of Differentially Expressed Proteins in Chicken Trachea and Kidney After Infection with the Highly Virulent and Attenuated Coronavirus Infectious Bronchitis Virus in Vivo. Proteomo Science, 24(10), 1-19.

Campbell N.A., Jane B.R., Lisa G. M., Michael L.C., Steven A.W., Peter V.M., \& Robert B.J. (2008). Biologi: Edisi kedelapan Jilid Tiga. Jakarta: Erlangga.

Dharmayanti N.L.P.I., \& Risa I. (2017). Identification and Characterization of Infectious Bronchitis Virus (IBV) in Indonesia (Identifikasi dan Karakterisasi Virus Infectious Bronchitis (IBV) di Indonesia). Jurnal Biologi Indonesia, 13(1), 53-59.

Direktorat Kesehatan Hewan. (2014). Manual Penyakit Unggas. Jakarta: Bingkai Pertanian

Ghadakchi., Dadras H., Pourbakhsh S.A., \& Hosseini S. (2005). Standardization of an Enzyme-Linked Immunosorbent Assay for Detection of Infectious Bronchitis Virus Antibody. Arch Razi Ins, (59), 75-83.

Hasnita, Dian M., \& Hamdani B. (2017). Gambaran Histologis Bursa Fabricius Ayam Kampung (Gallus gallus domesticus) pada Umur Berbeda. JIMVET, 01(3), 398-403.

Indriani, R \& Ni Luh P.I.D. (2013). Studi Efikasi Vaksin Bivalen AI Isolat Lokal terhadap Beberapa Karakter Genetik Virus AI subtipe H5N1. Jurnal Biologi Indonesia, 9(1), 21-30.

Jiang W., Sarah C., Julian N.R., George A.O., Bradley J.S.O., \& Donald P.W. (2014). A Rapid LiveCell ELISA for Characterizing Antibodies Against Cell Surface Antigens of Chlamydomonas Reinhardtii and Its Use in Isolating Algae from Natural Environments with Related Cell Wall Components. BMC Plant Biology, 14(244), 1-12.

Kencana G.A.Y., Nyoman S., Mesakh P.S., Arini N.H, Steffi O., Syamsidar, \& Aprillia K. (2015). Respons Antibodi terhadap Penyakit Tetelo pada Ayam yang Divaksin Tetelo dan Tetelo-Flu Burung. Jurnal Veteriner, 16(2), 289-290.

Kencana G.A.Y., Nyoman S., Ni Made A.S.P, \& Arini.N.H. (2016). Vaksin Kombinasi Newcastle Disease dengan Avian Influenza Memicu Imunitas Protektif pada Ayam Petelur terhadap Penyakit Tetelo dan Flu Burung. Jurnal Veteriner, 17(2), 257-264.

Kencana G.A.Y., Nyoman S., Daniel R.B.N, \& Agatha S.L.T. (2017). Respons Imun Ayam Petelur Pascavaksinasi Newcastle Disease dan Egg Drop Syndrom. Jurnal Sain Veteriner, 35(1), 81-90.

KPL. (2013). Technical Guide for ELISA. Sera Care Life Science: 10.

Lougovskaia N., Andrei A., Yuri A.B., Galina V.B., Natalia S.M., Vlamidir V.D., Alexander V.B., Vladimir V.B., \& Anatoly A.G. (2010). Deteksi dan Estimasi Antigen Virus Bronkitis Menular Burung dengan Fase Liquid Tidak Langsung Novel Memblokir Enzim-Linked Immunosorbent Assay Menggunakan Ayam dan Kelinci Afinitas Imunoglobulin Dimurnikan. Avian Patologi, (31), 549-557.

Putri D. D., Agung A.C., \& Zairiful. (2012). Waktu Vaksinasi Avian Influenza (AI) yang Tepat untuk Menghasilkan Respon Imunologis Protektif pada Ayam Ras Pedaging. Jurnal Penelitian Pertanian. 
Sasipreeyajan J, Pohuang T, dan Sirikobkul N. (2012). Efficacy of Different Vaccination Programs against Thai QX-like Infectious Bronchitis Virus. Vet Med, 42(1), 73-79.

Sattler T., Eveline W, Sandra R.F., \& Friedrich S. (2014). Comparison of Different Commercial Elisas for Detection of Antibodies Against Porcine Respiratory and Reproductive Syndrome Virus in Serum. BMC Veterinary Research, 10(300), 2-6.

Siswanto I., Nyoman S., \& I Gede S. (2016). Titer Antibodi dan Hitung Jenis Leukosit Ayam Potong Jantan pasca Vaksinasi Virus Newcastle Disease. Indonesia Medicus Veterinus, 5(1), 89-95.

Suryadi Y., Ifa M., \& Machmud. (2009). Potensi Pemanfaatan Perangkat Diagnostik ELISA serta Variannya untuk Deteksi Patogen Tanaman. Jurnal Agrobiogen, 5(1), 39-48.

Syukron, M.U., Nyoman S., \& Nyoman S.D. (2013). Serodeteksi Penyakit Tetelo pada Ayam di Timor Leste. Indonesia Medicus Veterinus, 2(3), 360-368.

Yuan Y., Zhi-Peng Z., Yi-Ning H., Wen-Sheng F., Zhi Hua D., Li-Hua Z., Xin-Kuan S., Li-Li S., TianChao W., Mei-Lan M., \& Ping W. (2018). Protection against Virulent Infectious Bronchitis Virus Challenge Conferred by a Recombinant Baculovirus Co-Expressing S1 and N Proteins. Viruses, (10), 347. 